\title{
APPLICATION OF COOPERATIVE LEARNING TYPE PICTURE TO PICTURE TO INCREASE STUDENT'S COMPREHENSION ON SOCIAL STUDIES
}

\author{
Deden Herdiana Altaftazani ${ }^{1}$ \\ ${ }^{1}$ IKIP Siliwangi \\ ${ }^{1}$ altaftazani27@gmail.com
}

\begin{abstract}
This research is based on the result of observation in the fourth grade students SDN Taman Kopo Indah. When learning activities take place, Researchers found the various problems. These problems lead to low comprehension of students. This study aims to determine Whether students' comprehension can improve After the implementation of model cooperative learning type picture to picture in social science learning. The research method used is Classroom Action Research Which refers to the Kemmis and Mc Taggart models. This research is done with the stages of planning, implementation, observation, and reflection. This study was conducted in 3 action cycles. The results obtained are: The average percentage of students' complete mastery in the first cycle of $45 \%$, In the second cycle increased by $35 \%$ to $80 \%$, And cycle III increased by $5 \%$ to $85 \%$. so, it is recommended for teachers to implement cooperative learning model type of picture to picture in the social science learning.
\end{abstract}

Key words: Cooperative Learning type Picture to Picture, students' comprehension, social science learning

\begin{abstract}
Abstrak
Penelitian ini didasari oleh hasil observasi pada siswa kelas IV SDN Taman Kopo Indah. Ketika kegiatan pembelajaran berlangsung, Peneliti menemukan berbagai masalah. Masalah-masalah ini menyebabkan rendahnya pemahaman siswa. Penelitian ini bertujuan untuk mengetahui apakah pemahaman siswa dapat meningkat Setelah penerapan model pembelajaran kooperatif tipe gambar untuk gambar dalam pembelajaran ilmu pengetahuan sosial. Metode penelitian yang digunakan adalah Penelitian Tindakan Kelas yang mengacu pada model Kemmis dan Mc Taggart. Penelitian ini dilakukan dengan tahapan perencanaan, pelaksanaan, observasi, dan refleksi. Penelitian ini dilakukan dalam 3 siklus tindakan. Hasil yang diperoleh adalah: Persentase rata-rata penguasaan lengkap siswa pada siklus pertama $45 \%$, pada siklus kedua meningkat sebesar $35 \%$ menjadi $80 \%$, dan siklus III meningkat sebesar $5 \%$ menjadi $85 \%$. Oleh karena itu, disarankan bagi guru untuk menerapkan model pembelajaran kooperatif tipe gambar untuk gambar dalam pembelajaran ilmu sosial.
\end{abstract}

Kata Kunci: Pembelajaran Kooperatif tipe Picture to Picture, pemahaman siswa, pembelajaran sains sosial

\section{INTRODUCTION}

The curriculum of primary and secondary education shall contain religious education, civic education, language, sciences, social science learning, arts and culture, physical and sports education, skills / honesty, local content (UU no 20 thn 2003). It is clear that Social science learning (IPS) is one of the subjects that must be taught in schools, especially in elementary school level. Social science learning is expected to develop students' values, attitudes and social skills To be able to live the social life. As mentioned in the Permendiknas 
document Explained that social science learning examines a set of events, facts, concepts and generalizations related to social issues (Sapriya et al, 2006: 6)

But the expected learning objectives were not in accordance with what happened in the field. A lot of problems that exist in a learning process. Through a teaching observation in SDN Taman Kopo Indah, We found a lot of problems that happened When the learning process takes place. Such as students unable to explain back material presented by the teacher, Students can not make a summary of the content of the material, And students can not give examples of the material being discussed. It also impact on test results, More than $60 \%$ of students score below the minimum mastery criteria (KKM). It shows that students' comprehension is low. These problems happen because of various factors, One of them is teacher factor. No innovative learning models make the learning process boring, Teachers only write, or dictate, or simply provide explanations through one interaction only. Learning is still teacher-centered. Though learning will be interesting if the learning centered on the students.

Lots of learning models that can be used In the social science learning learning process. One of them is model Cooperative learning type picture to picture. Group learning can make it easier for students to understand a learning material. Johnson \& Johnson stated that the main goal of cooperative learning is to maximize student learning to improve academic achievement and understanding both individually and in groups (Trianto, 2009: 57). This learning comes from the concept that students will more easily find and understand difficult concepts if they discuss with their friends (Trianto, 2009: 56). This model used picture as the main tool in teaching and learning process. Suprijono (Huda, Miftahul 2013: 236), picture to picture is a learning strategy that uses images as a learning tool. Cooperative learning model of picture to picture type is a model where teachers use tools or media images to explain a material or facilitate students to actively learn. The picture to picture type is a learning method that uses images and is paired or sorted into a logical sequence (Hamdani, 2010; 89).

The steps of implementation Model cooperative learning type picture to picture (Istarani, 2011: 7) :

1. Teachers convey the purpose of learning or competence to be achieved

2. Provide introductory material before the activity

3. The teacher provides the images to be used (related to the material).

4. The teacher appoints students in rotation to sort or pair the pictures. 
5. The teacher asks questions about the reason of the students in determining the sequence of images.

6. From that reason the teacher will develop the material and embed the concept of material in accordance with the competence to be achieved

7. Master conveys the conclusion. At the end of the lesson, the teacher and the students conclude as a reinforcement of the subject matter.

Excess model coperative learning tipe picture to picture (Miftahul Huda, 2013:239)

1. The teacher is more aware of the ability of each student

2. Students are trained to think logically and systematically

3. Students are assisted to learn to think based on the point of view of a subject by giving students freedom in practice thinking

4. Motivate students to grow

5. Students are involved in class planning and management

\section{Comprehension}

Skills and intellectual abilities that are demanding in schools and colleges, that is comprehension engagement. That is, when students are faced with communication, is expected to know what is being communicated and can use the ideas contained in it. (Wowo Sunaryo, 2012 : 43). Comprehension is a condition where students already have knowledge about a thing by adding new knowledge that they get in the learning process. So that there is a connection between their old knowledge and the findings of their new knowledge which will eventually produce a new knowledge.Indicators of comprehension by Wowo Sunaryo (2012: 124) are:

1. Interpreting, is to change from one form of image to another.

2. Provide, examples of finding case examples or illustrations of concepts or principles

3. Classify, that is determining something into a category

4. conclude, that is summarizes the general or specific theme

5. Suspect, that is to describe the logical conclusion of the existing information

6. Compares, that is detects correspondence between two ideas, objects.

7. Explain, that is creating a system of causes and influence models

\section{METHOD}

The research method used is classroom action research. This classroom action research is a research done by a teacher or researcher in his own class through self-reflection, 
With the aim to improve its performance as a teacher so that student learning outcomes increase. classroom action research is an action research conducted by teachers who simultaneously as researchers in their classes or together with others (collaboration) by designing, implementing and reflecting collaborative and participatory actions aimed at improving or improving the quality of the learning process in its class through A certain action (treatment) in a cycle (Kunandar, 2008:44).

The focus of classroom action research is on students or learning that takes place in the classroom. The main purpose of classroom action research is to solve real problems that occur in the classroom and increase the teacher's actual activities in its professional development activities. Classroom action research is very important done by the teacher, because by doing this research can make the teacher become better in implementing learning.The classroom action research model used is a research model developed by Kemmis and Mc Tagart (Kunandar, 2008: 70). Classroom action research is done through a dynamic process consisting of four main steps: planning, action, observation, and reflection. Preliminary

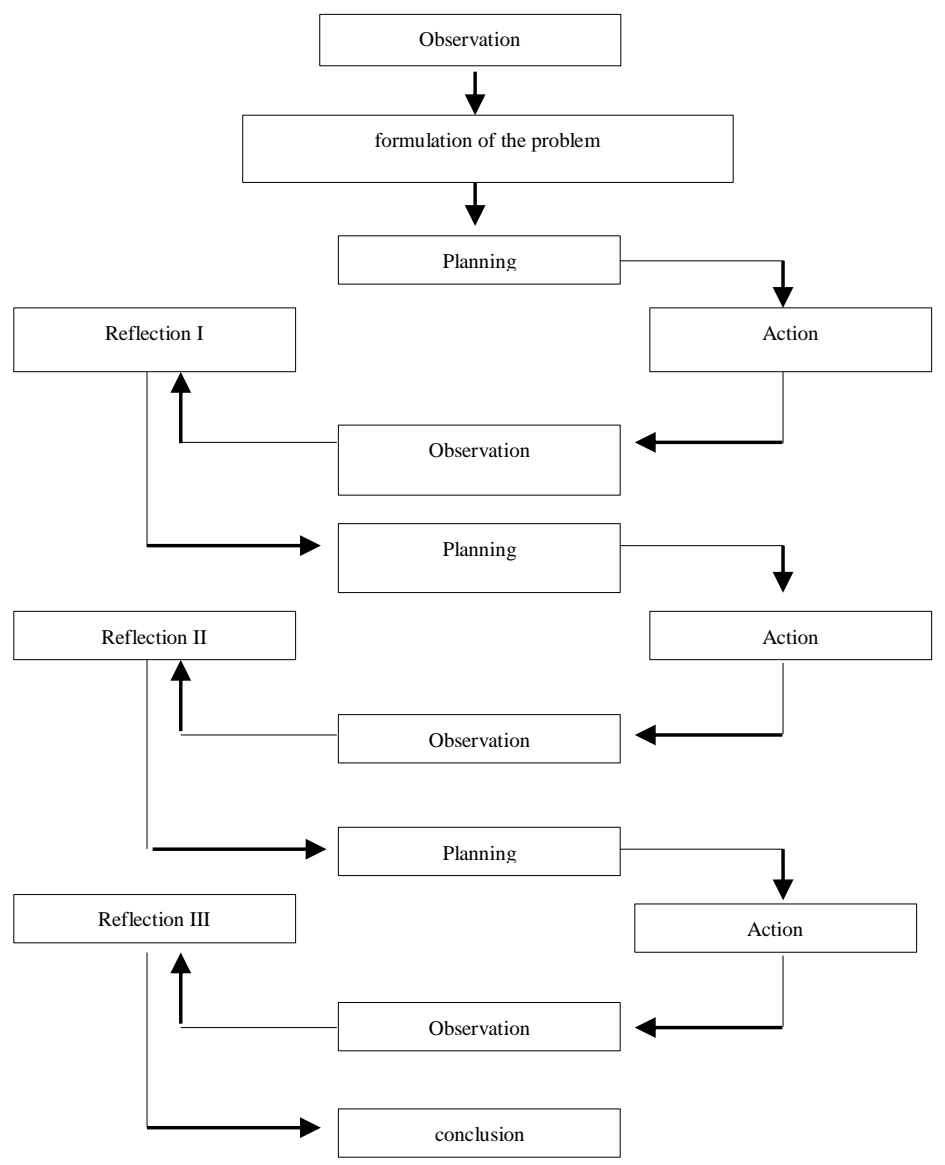

Figure 1. Classroom action research flow 


\section{RESULTS AND DISCUSSION}

\section{Results}

At this point it will discuss the improvement of students' comprehension on cycles I, II and III. In this study, researchers took 5 indicators that can be seen as a reference to increase student comprehension :

1. Interpret (C2.1)

2. Exemplify (C2.2)

3. Classify (C2.3)

4. Compare (C2.6)

5. Explain $(\mathrm{C} 2.7)$

To see students' improvement in comprehension, researchers used the evaluation test As a reference for improving students' comprehension. The questions in the evaluation test are based on these 5 indicators.

Table 1. Indicators of comprehension

\begin{tabular}{|c|c|c|}
\hline No & Soal & Indikator \\
\hline 1 & Apa yang dimaksud dengan teknologi? & $\begin{array}{l}\text { Mengartikan } \\
\text { (Interpret) }\end{array}$ \\
\hline 2 & $\begin{array}{l}\text { Berikan masing-masing } 3 \text { contoh teknologi sederhana dan } \\
\text { teknologi modern? }\end{array}$ & $\begin{array}{l}\text { Mencontohkan } \\
\text { (Exemplify) }\end{array}$ \\
\hline 3 & $\begin{array}{l}\text { Kelompokan benda-benda dibawah ini sesuai dengan jenis } \\
\text { teknologi nya (sederhana dan modern) ? }\end{array}$ & $\begin{array}{l}\text { Mengklasifikasikan } \\
\text { (Classify) }\end{array}$ \\
\hline 4 & $\begin{array}{l}\text { Sebutkan keuntungan dan kerugian menggunakan teknologi } \\
\text { sederhana dan modern? }\end{array}$ & $\begin{array}{l}\text { Membandingkan } \\
\text { (Compare) }\end{array}$ \\
\hline 5 & $\begin{array}{l}\text { Jelaskan apa yang dimaksud dengan teknologi produksi, } \\
\text { komunikasi dan transportasi? }\end{array}$ & $\begin{array}{l}\text { Menjelaskan } \\
\text { (Explain) }\end{array}$ \\
\hline
\end{tabular}

From result of action during 3 cycle is obtained data that in first cycle, From 30 students only $50 \%$ or 15 students who have achieved Minimum Exhaustiveness criteria (KKM) and as many $50 \%$ or 15 students declared unfinished. In this cycle the success is minimal. Then in the second cycle, out of 30 students, $83 \%$ or 25 students have reached the Minimum Exhaustiveness Criteria (KKM) and $17 \%$ or 5 students expressed unfinished. The success rate in the second cycle is very high compared to the first cycle. 
While in the third cycle is the culmination of the success of this study, 93\% or 28 students reach Minimum Efficiency criteria (KKM). The success rate in this cycle increases compared with the second cycle. From the results of these three cycles, its success continues to increase. It can be said that students' understanding continues to increase.

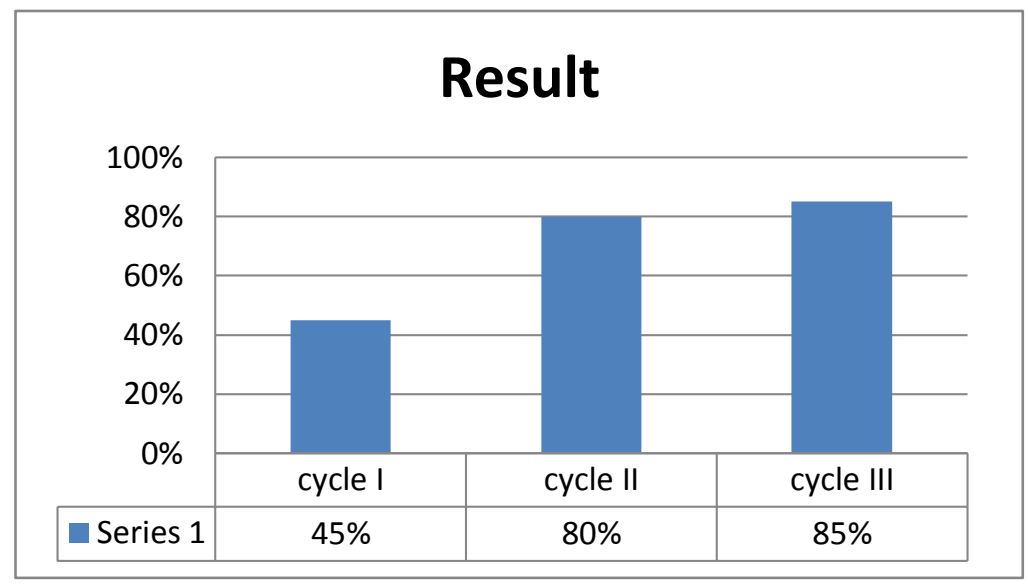

Figure 2. Result of cycle

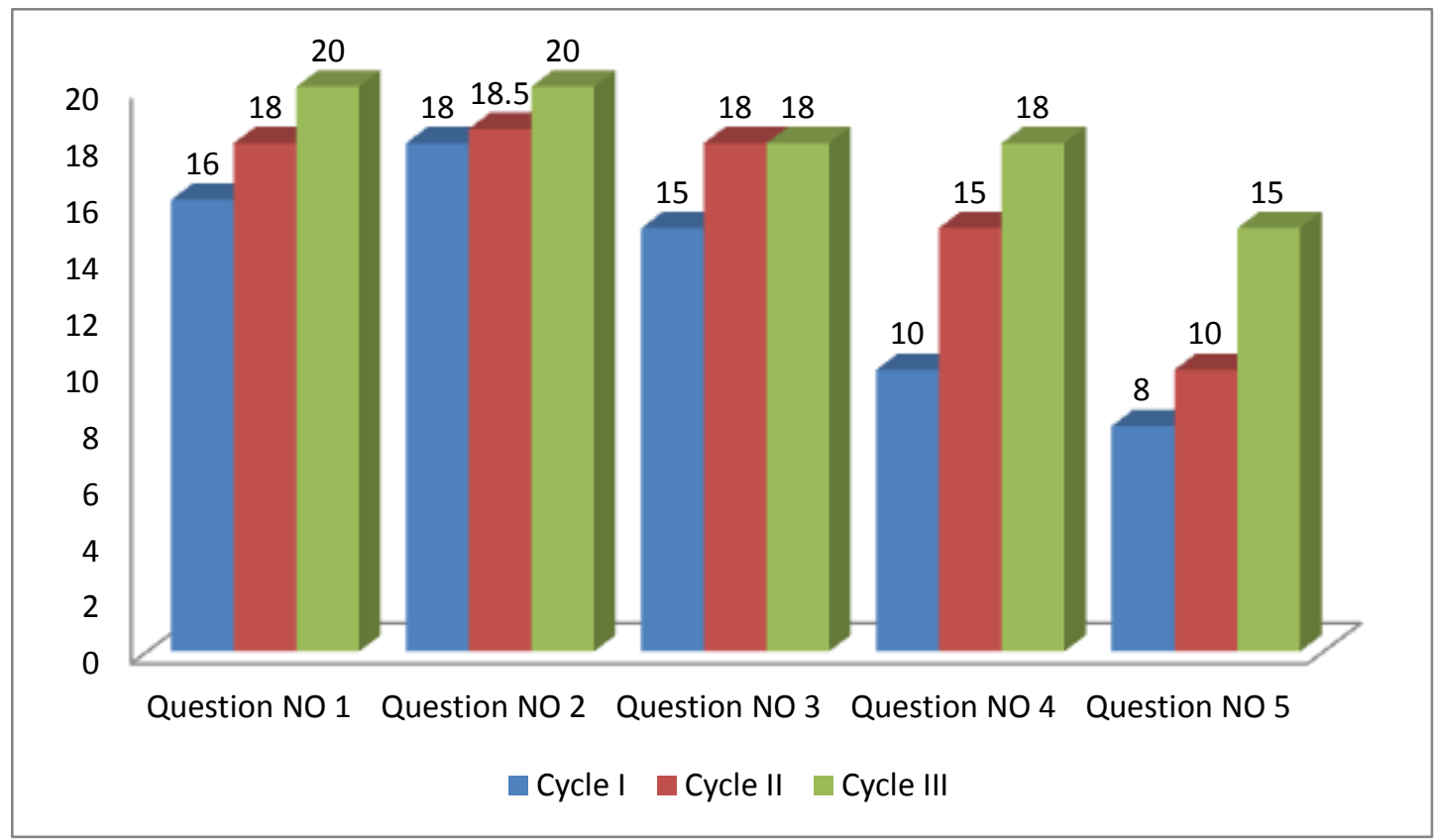

Figure 3. Result of Indicators

\section{Discussion}

From the results of the research obtained, we can see that by using a cooperative model type picture to picture, students' understanding of social studies learning material technology development continues to increase each cycle. this proves that the learning model is effective in improving students' understanding abilities. this is supported by various 
advantages possessed by this learning model, as stated by Miftahul Huda (2013: 239), where the cooperative model of picture to picture type has the following advantages:

1. The teacher knows more about each student's abilities

2. Students are trained to think logically and systematically

3. Students are assisted in learning to think based on the point of view of a subject of discussion by giving students freedom in thinking practice

4. Motivate students to develop more

5. Students are involved in classroom planning and management

\section{CONCLUSION}

It can be concluded that after application of cooperative learning type picture to picture in social science learning, There is increasing student's comprehension in each cycle. This is evident from the difference in average scores and the percentage of success from cycle one to third cycle. Students' comprehension always increased from only $45 \%$, then rose to $80 \%$, until last touched success of $85 \%$. In addition, the average value is always an increase in the average value where in the third cycle, the average value of the class reached eighty.

Based on the above conclusions, then some suggestions are given:

1. For elementary school teachers, the application of cooperative learning model of picture to picture type can be used as a recommendation on the learning process in general, And especially on the social science learning in an effort to improve students' comprehension. By applying the cooperative learning type picture to picture, teachers can help students build knowledge because the image is able to bring up an abstract idea to be concrete. Learning using this model is very fun, so it can eliminate bored and saturated during the learning process, learning becomes more innovative so as to improve student learning outcomes.

2. For researcher, can do further research about applying cooperative learning type picture to picture to improve education quality in Indonesia in the future. And this research can be used as reference and study materials related to the application of cooperative learning type picture to picture, and can be useful for other researchers

3. For schools, schools can provide various facilities that can support teachers to implement learning models using cooperative learning type picture to picture. 


\section{REFERENCES}

Huda. Miftahul, 2013. Model-model pengajaran dan pembelajaran (isu-isu metodis dan paradigmatis). Yogyakarta : Pustaka Pelajar

Istarani, 2011.58 Model Pembelajaran Inovatif (Referensi Guru Dalam Menentukan Model Pembelajaran).Medan : Media Persada.

Kunandar (2008). Langkah-langkah Mudah Penelitian Tindakan Kelas Sebagai Pengembangan Potensi Guru. Jakarta: Rajagrafindo Persada

Kuswana, Sunaryo. Wowo (2012). Taksonomi Kognitif. Bandung : PT Remaja Rosdakarya

Hamdani. 2011. Strategi Belajar Mengajar. Bandung: Pustaka Setia

Sapriya, dkk. 2006. Konsep Dasar IPS. Bandung: UPI Press Bandung

Suharsimi, A, dkk. (2009). Penelitian Tindakan Kelas. Jakarta : PT Bumi Aksara.

Trianto, (2007). Model-model pembelajaran inovatif berorientasi konstruktivistik. Jakarta : Prestasi pustaka

Prihanto.Subkhi.(2013). Penerapan model tipe picture to picture untuk meningkatkan hasil belajar siswa pada pembelajaran IPA.Skripsi pada Program studi PGSD Bumi siliwangi FIP UPI. Bandung. Tidak ditertibkan. 